\title{
Microbial Diversity in Continuous Flow Constructed a Wetland for the Treatment of Swine Waste Ibekwe $\mathrm{AM}^{1 *}$, Ma $\mathrm{J}^{1,2}$, Murinda $\mathrm{S}^{3}$ and Reddy $\mathrm{GB}^{4}$
}

${ }^{1}$ USDA-ARS, U.S. Salinity Laboratory, 450 W Big Springs Rd, Riverside, CA 92507, USA

${ }^{2}$ College of Environment and Resources, Jilin University, Changchun, Jilin Province, 130021, P. R. China

${ }^{3}$ Department of Animal and Veterinary Sciences, California State Polytechnic University, Pomona, CA 91768, USA

${ }^{4}$ Department of Natural Resources and Environmental Design, North Carolina Agricultural and Technical State University, Greensboro, NC 27411, USA

\begin{abstract}
Contaminant removal may largely be a function of many microbial processes in constructed wetlands. However the role of microbial diversity for the removal of swine waste in constructed wetlands is limited. Here, we used 454/ GS-FLX pyrosequencing to assess archaeal, bacterial, and fungal composition within a surface flow constructed wetland to determine their spatial dynamics and contaminant removal within the wetland. We analyzed our data using UniFrac and principal coordinate analysis (PCoA) to compare community structure and specific functional groups of bacteria, archaea, and fungi in different sections of the wetland. PCoA analysis showed that, bacterial, archaeal, and fungal composition were significantly different $(p=0.001)$ for the influent compared to the final effluent. Our results showed that, the wetland system contained relatively higher proportions of bacteria and fungi than archaea. Most of the bacteria and archaea that were associated with nitrogen removal were affiliated with Nitrosomonas which are ammonia oxidizing bacteria (AOB), Candidatus Solibacter, an anaerobic ammonia oxidizing bacteria (Anammox), as well as Nitrosopumilus, ammonia oxidizing archaea (AOA). The detection of AOB, Anammox, and AOA in this wetland shows abundance and diversity of these microorganisms that are responsible for nitrification processes in constructed wetlands.
\end{abstract}

Keywords: Constructed wetland; Contaminants; Pyrosequencing; Microbial communities; Swine; Wastewater

\section{Introduction}

Constructed wetland $(\mathrm{CW})$ is a natural process for the treatment of waste from a variety of sources [1-3]. They are cost-effective, ecologicallyfriendly, and a simple alternative to conventional technologies for wastewater treatment $[3,4]$. It has also been shown that, significant benefits to human populations in both [2] developed and developing countries can be achieved through constructed wetlands, and these benefits may include water-quality improvement, water reclamation, conservation of habitat for species, flood control, recreational and educational activities [1,4-7]. North Carolina is one of the largest swine producing states in the United States [2], and waste disposal was traditionally done by flushing into anaerobic lagoons and then later sprayed on agricultural fields. This resulted in swine waste from large swine farms polluting surface and well waters [8]. During hurricane Floyd in 1999 many North Carolina hog waste lagoons overflew [2] and polluted many surface water systems with fecal indicator bacteria from compromised septic and municipal sewage systems, and livestock waste lagoons [8]. After the storm, North Carolina invested resources [2] into new, cost-effective technologies for waste disposal, and one such technology was constructed wetlands for the treatment of swine waste. As a result, a pilot constructed wetland for the treatment of swine waste was evaluated at [2] North Carolina Agricultural and Technical State University (Greensboro NC, USA). The wetland system uses [2] natural plants for the removal of nitrogen $(\mathrm{N})$, phosphorus $(\mathrm{P})$, solids, and Chemical Oxygen Demand (COD) from treated swine wastewater, resulting in a cleaning final effluent [9].

The removal efficiency by constructed wetlands has been shown to be a function of diverse microbial communities [10]. However, there is a general lack of information on the diversity and changes of the microbial communities in long-term constructed wetlands treating swine waste [2]. Work on bacterial diversity in constructed wetlands is well documented, whereas the role played by archaea and fungi is not clear. The main contaminants from swine waste [2] may include nutrients, salts, microbes, including pharmaceutically active compounds, and their removal involves complex physical, chemical, and biological processes [2]. The aim of the current study was to compare the composition of microbial communities in a continuous surface flow constructed wetland used for the treatment of swine waste using pyrosequencing.

\section{Materials and Methods}

\section{Experimental site and sampling}

The experiment was conducted at a swine research facility at North Carolina Agricultural and Technical State University farm in Greensboro, NC, USA. This was a continuous flow constructed wetland originally built in March 1996 [11] (Figure 1), and planted with Typha latifolia L. (broadleaf cattail) and Schoenoplectus americanus (PersAmerican bulrush). The wetland has six cells and each cell is $40 \mathrm{~m}$ long and $11 \mathrm{~m}$ wide. In 2003, a modification was made to cells 5 and 6 [11] to achieve a continuous marsh system with a slope of $0.33 \%$ (Figure 1 ). The new sections were planted with giant bulrushes (Scirpus californicus) as previously noted [11]. Sixty-five to 115 pigs were managed in the swine house between January 2007 and January 2012. Samples were collected from eight different points from different sections of the wetland in

*Corresponding author: Abasiofiok Mark lbekwe, USDA-ARS-U. S. Salinity Laboratory, 450 W Big Springs Rd, Riverside, CA 92507, Tel: 951-369-4828; Fax: 951-342-4964; Email: Mark.lbekwe@ars.usda.gov

Received June 12, 2017; Accepted June 16, 2017; Published July 22, 2017

Citation: Ibekwe AM, Ma J, Murinda S, Reddy GB (2017) Microbial Diversity in Continuous Flow Constructed a Wetland for the Treatment of Swine Waste. Hydrol Current Res 8: 277. doi: 10.4172/2157-7587.1000277

Copyright: ( 2017 lbekwe AM, et al. This is an open-access article distributed under the terms of the Creative Commons Attribution License, which permits unrestricted use, distribution, and reproduction in any medium, provided the original author and source are credited. 
duplicate in November 2012. Grab samples were collected sequentially from effluent from the swine house, lagoon 1, lagoon 2, and the 8,000 L storage tank. More samples were collected from continuous wetland cell influent, final effluent samples, storage pond, and the final recycled effluent. The wetland cell received $10 \mathrm{~kg} / \mathrm{ha} /$ day with a hydraulic load of $3.8 \mathrm{~m}^{3} /$ day. Samples were stored on ice and taken to the laboratory for further analysis. All samples were analyzed for ammonium $\left(\mathrm{NH}_{4}^{+}-\mathrm{N}\right)$, nitrate $\left(\mathrm{NO}_{3}-\mathrm{N}\right)$, total-phosphate $(\mathrm{TP})$ and available-phosphate $\left(\mathrm{PO}_{4}^{3-}\right)$ using a flow injection analysis instrument (Lachat-QuikChem 8000, Loveland, CO, USA), as well as carbon (C) and nitrogen (N) concentrations using the Perkin-Elmer 2400, CHNS/O series II Analyzer (Shelton, CT, USA) [4].

\section{DNA extraction and Pyrosequencing}

Total bacterial DNA was extracted from effluent samples using Power Water DNA kits (MO BIO, Inc., Solana Beach, CA), according to the manufacturers' protocol. DNA extracts from duplicate samples (200 ng) were pooled. Extracted DNA $(2 \mu \mathrm{L})$ was quantified using the NanoDrop ND-1000 spectrophotometer (NanoDrop Technologies, Wilmington DE), and run on a $1.0 \%$ agarose gel before it was used for pyrosequencing. DNA was stored at $-20^{\circ} \mathrm{C}$ prior to pyrosequencing analysis. The DNA samples $(15.0 \mu \mathrm{l})$ were then submitted to Research and Testing Laboratories (Lubbock, TX) for polymerase chain reaction (PCR) optimization and pyrosequencing analysis. Bacterial tag-encoded FLX amplicon pyrosequencing was conducted on the 16S rRNA gene for amplification of bacteria and archaea sequences, whereas the microbial tag-encoded FLX amplicon was used for amplification of $18 \mathrm{~S}$ rRNA gene sequences in fungi. Pyrosequencing (TEFAP) procedures described earlier [12] based on 16S rRNA genes for archaea (V3-V5 regions) and bacteria (V1-V3 regions) with primer pairs, 340F90 (GYGCASCAGKCGMGAAW)/806R96 (GGACATCVSGGGTATCTAAT) and 28F

( G A G T T T G A T C N T G G C T C A G ) / 519 R (GTNTTACNGCGGCKGCTG), respectively, were employed. The fungal $18 \mathrm{~S}$ rRNA gene was amplified using the primer pair, SSUF (TGGAGGGCAAGTCTGGTG)/ funSSUR(TCGGCATAGTTTATGGTTAAG). Pyrosequencing data were analyzed using the dist. seqs function in MOTHUR, version 1.9.1 [13]. Raw reads were treated as previous described [14] using the Pyrosequencing Pipeline Initial Process of the Ribosomal Database Project (RDP), to sort the data, trim off the adapters, barcodes and primers using the default parameters, and to remove ambiguous ' $\mathrm{N}$ ' [15]. Sequence libraries were further resampled to obtain similar numbers of sequences for diversity and richness estimations [16]. All sequence reads with a quality score 20 and a read length 200 bp were removed. Shannon's diversity index values $\left(\mathrm{H}^{\prime}\right)$, and Chao estimates were calculated from MOTHUR as well as operational taxonomic units (OTUs, 97\% similarity). We used RDP Classifier with a bootstrap cutoff of $80 \%$ for taxonomic classification of the bacterial sequences. We used the keep first $200 \mathrm{bp}$ commands in MOTHUR to eliminate sequencing noise resulting in a sequence read fragment covering the $18 \mathrm{~S}$ region and aligned to the SILVA database for further analysis of data as stated above.

\section{Statistics and analysis of pyrosequencing data}

SAS version 9.1 [17] was used to conduct analysis of variance (ANOVA) to determine differences in wetland properties. PCoA and UniFrac analysis were carried out using MOTHUR to group microbial communities of different samples into different taxonomic groups using the RDP Classifier. RDP Complete Linkage Clustering was also used to generate OTUs and weighted UniFrac from all samples [18]. The relaxed neighbor-joining algorithm in Clearcut (version 1.0.9) [19] was used for the construction of phylogenetic trees and the parsimony test (P-values of 0.05) in Treeclimber [20] was used for between-site comparisons.

\section{Results}

\section{Nutrient removal}

There were significant decreases $(\mathrm{P}<0.05)$ in total $\mathrm{N}$, ammonium $\left(\mathrm{NH}_{4}^{+}\right)$, and total suspended solids (TS) in wetlands from the lagoon to the final effluent (Figure 2). The removal rates of $\mathrm{N}^{2}$ and $\mathrm{NH}_{4}^{+}$in this study were above $70 \%$ from the influent to the effluent and this was similar to what had been previously reported $[9,21]$. The removal rate of total and organic phosphorus was low between the lagoon and the effluent samples. The removal rates of total and suspended solids were significantly higher $(\mathrm{P}<0.01)$ between lagoon and the final effluent [18].

\section{Community composition, diversity, and estimated richness}

A total of 6354, 81234, and 50719 sequence tags for archaea, bacteria, and fungi, respectively, were generated through 454 pyrosequencing (Tables 1-3). The total numbers of OTUs were 661, 8429, and 1946 for archaea, bacteria, and fungi, respectively (Table S1-S3). For the archaea, the highest number of sequences was found in storage pond while the lowest was in the final effluent (Table 1). For bacterial the highest sequence tag was from lagoon while the lowest was from mid marsh (Table 2). Furthermore, for fungi, the highest sequence tag was found in samples collected from storage pond and the lowest from mid marsh (Table 3). We normalized our data to the smallest sequence tag, for reanalysis to show normal distribution of variances (Table S1-S3). Shannon diversity index $\left(H^{\prime}\right)$ showed variations in diversity among the different wetland segments with the highest archaeal and fungal

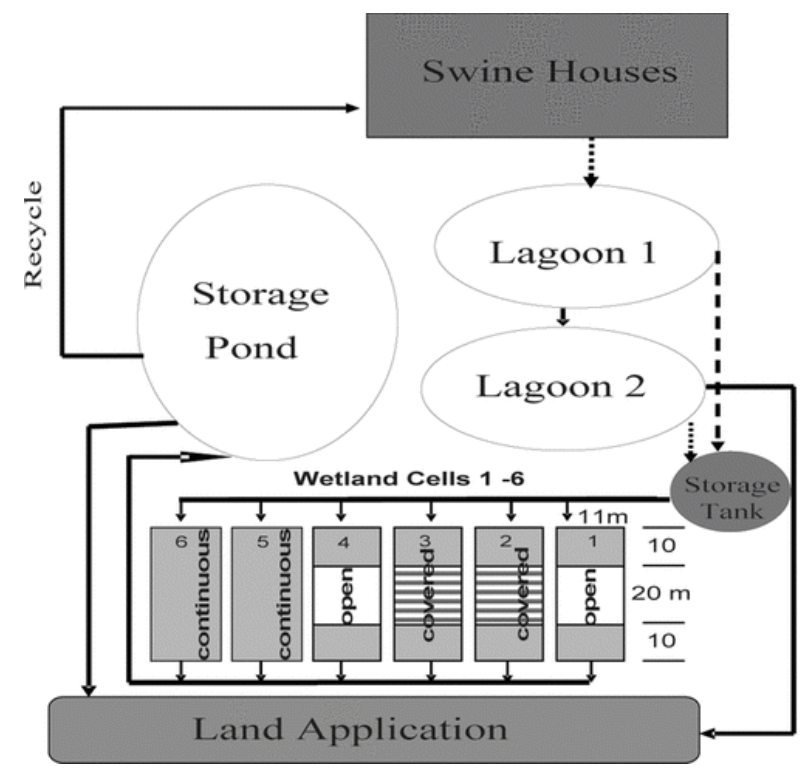

Figure 1: Wetland cells $40 \mathrm{~m}$ long $11 \mathrm{~m}$ wide constructed in 1995. Each cell consisted of $11 \mathrm{~m}$ by $10 \mathrm{~m}$ marsh at both influent and effluent and $11 \mathrm{~m}$ by $20 \mathrm{~m}$ pond section separating the marshes and planted with Typha latifolia L. (broadleaf cattail) and Scirpus americanus (bulrush) in March 1996. The marsh and pond sections of wetlands have previously been described $[2,4]$. 


\begin{tabular}{|c|c|c|c|c|c|c|c|}
\hline Group & nseqs & OTUs & chao & invsimpson & npshannon & simpson & coverage \\
\hline S1 & 630 & 51 & 132.2 & 5.333953 & 2.361805 & 0.187478 & 0.953968 \\
\hline S2 & 952 & 111 & 354.83333 & 7.096459 & 3.043943 & 0.140915 & 0.919118 \\
\hline S3 & 619 & 92 & 202.5 & 16.108388 & 3.530358 & 0.062079 & 0.915994 \\
\hline S4 & 3318 & 171 & 381 & 3.398484 & 2.161431 & 0.294249 & 0.968354 \\
\hline S5 & 257 & 76 & 130.66667 & 16.472709 & 3.830253 & 0.060706 & 0.840467 \\
\hline S6 & 280 & 89 & 149.05556 & 33.759723 & 4.180865 & 0.029621 & 0.832143 \\
\hline S7 & 163 & 41 & 167.5 & 11.094958 & 3.192706 & 0.090131 & 0.858896 \\
\hline S8 & 135 & 30 & 48.2 & 7.97619 & 2.842945 & 0.125373 & 0.896296 \\
\hline
\end{tabular}

Table 1: Total sequence tags for archaea generated from pyrosequencing from the wetland land units.

\begin{tabular}{|c|c|c|c|c|c|c|c|}
\hline Group & nseqs & OTUs & chao & invsimpson & npshannon & simpson & coverage \\
\hline S1 & 9201 & 751 & 1440.81 & 14.230392 & 4.141051 & 0.070272 & 0.953918 \\
\hline S2 & 11967 & 1683 & 3677 & 22.425723 & 5.147448 & 0.044592 & 0.916688 \\
\hline S3 & 12385 & 1233 & 2765.64 & 7.080288 & 4.102311 & 0.141237 & 0.940654 \\
\hline S4 & 10181 & 1222 & 2585.45 & 19.936472 & 4.683588 & 0.050159 & 0.927414 \\
\hline S5 & 6934 & 1268 & 2907.43 & 20.243401 & 5.272591 & 0.049399 & 0.88852 \\
\hline S6 & 10800 & 1758 & 3380.38 & 64.356874 & 6.053123 & 0.015538 & 0.914907 \\
\hline S7 & 10795 & 822 & 1809.5 & 25.159356 & 4.438501 & 0.039747 & 0.955998 \\
\hline S8 & 8971 & 1719 & 3653.54 & 87.078426 & 6.120541 & 0.011484 & 0.890313 \\
\hline
\end{tabular}

Table 2: Total sequence tags for bacteria generated from pyrosequencing from the wetland land units.

\begin{tabular}{|c|c|c|c|c|c|c|c|}
\hline Group & nseqs & OTUs & chao & invsimpson & npshannon & simpson & coverage \\
\hline s1 & 10340 & 135 & 345.789474 & 2.212453 & 1.255139 & 0.451987 & 0.991296 \\
\hline S2 & 8814 & 102 & 224.0625 & 1.167906 & 0.52713 & 0.856234 & 0.992852 \\
\hline S3 & 6987 & 556 & 1186.123457 & 27.501675 & 4.283528 & 0.036361 & 0.954201 \\
\hline S4 & 1761 & 180 & 390.416667 & 11.555549 & 3.552191 & 0.086539 & 0.942646 \\
\hline S5 & 4609 & 472 & 947.561644 & 12.476529 & 4.024419 & 0.08015 & 0.942721 \\
\hline s6 & 5554 & 201 & 439.214286 & 3.572661 & 2.243241 & 0.279903 & 0.979114 \\
\hline s7 & 9204 & 117 & 289.117647 & 1.770473 & 1.058795 & 0.564821 & 0.991634 \\
\hline S8 & 3450 & 183 & 414.875 & 5.192079 & 2.690632 & 0.192601 & 0.969275 \\
\hline
\end{tabular}

Table 3: Total sequence tags for fungi generated from pyrosequencing from the wetland land units.

diversity in the continuous flow effluent, while the highest bacterial diversity was from manure influent to the lagoon 1.

From our pyrosequencing data, the majority of archaeal sequences belonged to the phyla, Euryarchaeota (88.7\%) and Crenarchaeota $(5.21 \%)$, and at the class level Methanomicrobia (42.1\%), Thermoplasmata (26.25\%), and Methanobacteria (17.35\%) were dominant (Table 4). Bacterial sequences primarily comprised of the phyla, Proteobacteria (36.58\%), Bacteroidetes (18.15\%), Firmicutes (11.86\%) (Table 5). The most abundant fungal phylum was the Basidiomycota (86.3\%) (Table 6).

Using the greengenes database, we identified potential sequences at the genus level for specific functional groups of microorganisms that could perform specific functions in constructed wetlands (Table 7). These sequences were mainly from bacteria and archaea. We had a relatively low abundance of Nitrosomonas, which are ammonia oxidizing bacteria (AMO) in the midsection of the wetland. However, high sequences of a carbon degrader (CD) Roseburia were detected in this section of the wetland. Flavobacterium, Rhodobacter, Thauera, and Methylophilus are all denitrifying bacteria (DN), and as expected were found in relatively high abundance in this section of the wetland. Hydrogenophaga (hydrogen oxidizing bacteria) was also found in relatively high abundance. Candidatus Solibacter, an anaerobic ammonia oxidizing bacterium (Anammox), and Nitrosopumilus, an ammonia oxidizing archaea (AOA), were detected in this section of the wetland in relatively low numbers. The detection of both Anammox and $\mathrm{AOA}$ was not surprising since both are known to perform major functions in major water columns [22].

\section{Spatial phylogenetic structure of microbial community from different segments of the wetland}

We applied PCoA (Figure 3), and the UPGMA hierarchical clustering analysis (data not shown) to determine the distribution of microbial phylogenetic similarities and sorted them into different groups by applying UniFrac distance matrix using the UniFrac web interface in MOTHUR. The pattern for archaeal community dynamics was different from that of bacteria (Figure 3A). An archaeal sample from the swine house and lagoons clustered to the right, whereas, samples from storage tanks, wetland cells effluent, mid marsh effluent, and the final effluent for land application clustered to the left. These segments clustered closer to each other, which was the opposite for bacteria. As stated earlier, these four segments have already gone through the wetland lagoons and wetland cells, where most of the biological interactions with complex communities are occurring for the degradation of major compounds from the swine house waste (Figure 1). Bacterial community structures from wetland samples collected from the swine house and lagoons 1and 2 were significantly different $(\mathrm{p}<0.0001)$ based on parsimony tests (Figure 
3B) as wetland compounds were strong structural factors influencing bacterial assemblages $\left(\mathrm{R}^{2}=0.63, \mathrm{p}=0.0024\right)$. The PCoA (Figure $3 \mathrm{~B}$ ) showed samples from swine house and lagoons clustering to the left while samples from storage tanks, wetland cells effluent, mid marsh effluent, and the final effluent for land application clustered to the right. Furthermore, bacterial community structures from these four segments of the wetland were significantly different based on the parsimony test $(p<0.001)$, and this was confirmed by hierarchical clustering analysis (data not shown) with Jackknife supporting values. In general, the pattern of separations found in bacteria was also observed with fungal community structures in the different wetland segments.

\section{Discussion}

We employed 454 pyrosequencing techniques to quantify archaea, bacteria, and fungi community structures in a continuous flow constructed wetland. One major advantage of pyrosequencing is high-throughput and a large dataset of sequences, which can identify many microorganisms in a single analysis. As shown in this study, and from our previous study with bacteria [3], 16S rDNA sequences from different segments of the wetland may be used to determine the efficiency of the constructed wetland. This approach can monitor changes of microbial communities as waste flows through the wetland and has high potential for improving water quality based on bacterial concentrations. However, this technique does not quantify the members in the community in terms of cell number in the water samples, nor does it imply viability of the organism, but may demonstrate the presence of potential DNA sequences as shown in our previous study [23]. Here, we showed the diversity of microbial communities in relation to nutrient content in different sections of the constructed wetland fed with anaerobic lagoon swine wastewater. It has also been reported that, the bulk of the water quality improvement in constructed wetlands is due to microbial activities $[1,2,24]$. Archaeal, bacterial, and fungal OTUs from the influent were higher than from the effluent of the wetland. These results were associated with nutrient content differences in the different segments of the wetland where the concentrations of $\mathrm{TN}^{-\mathrm{NH}_{4}^{-}, \mathrm{TP} \text { and }}$ $\mathrm{PO}_{4}^{3-}$ decreased from lagoon to the final effluent (Figure 2). The results can be partly explained by the decrease in nitrogen and phosphorous, which are essential nutrients for microbial growth. This is different from the research results reported by Ipsilantis and Sylvia [25], where microbial counts did not consistently increase under elevated nutrient conditions due to carbon limitation. Nitrogen removal in wetlands has been documented to be the result of microbial activities, which play roles in the pathways of Anammox [26] and nitrification-denitrification [27]. In addition, P removal may partially depend on microbial activities via mineralization $[26,28]$ and immobilization.

We used pyrosequencing in this study to investigate the microbial diversity in the wetlands system because changes in environmental variables will likely have some influence on changes in OTUs. Archaea from storage tank samples displayed the highest species richness, diversity and evenness than samples from other segments of the wetland while results from the final effluent showed the lowest number of sequences; OTUs, and other diversity indices (Table 1). However, for bacteria and fungi, the highest diversity came from samples from wetland effluent, which has gone through the continuous marsh section of the wetland. The abundance, richness, and diversity of bacterial and fungal communities were considerably higher than archaea in a majority of the wetland cells (Table 2 and 3). This was similar to wetlands planted with Vetiveria zizanioides or Juncus effusus L. that showed much higher bacterial abundance but lower archaeal abundance [29]. In our study bacteria and fungi outnumbered archaea in all the wetland cells.

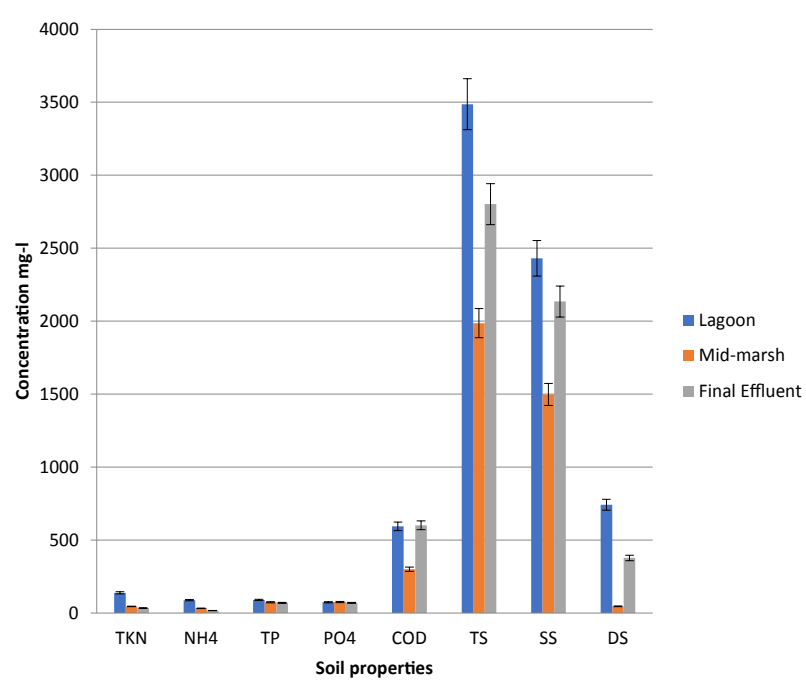

Figure 2: Nutrient removal in wetland samples collected in duplicated.

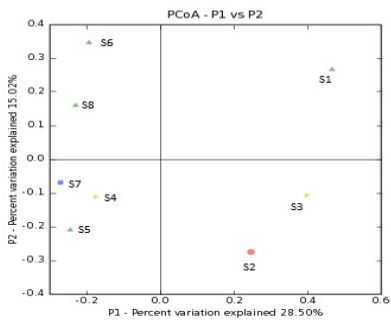

A: Archaea

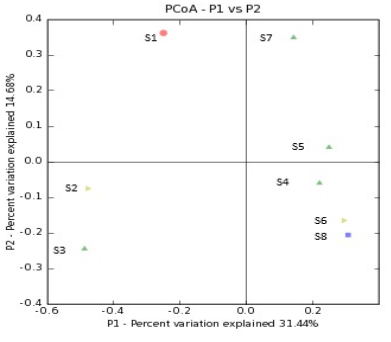

B: Bacteria

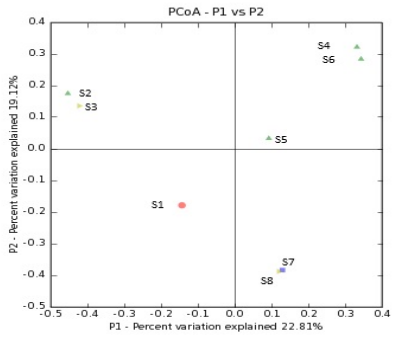

C: Fungi

Figure 3: The distribution of microbial phylogenetic similarity sorted into different groups by applying principal coordinates analysis (PCoA) spatially. All data were subjected to a matrix of UniFrac distances using the UniFrac web interface in MOTHUR.

Results from $\mathrm{PCoA}$ analysis confirmed that, $\mathrm{TN}, \mathrm{NH}_{4}^{-}$, $\mathrm{TP}$ and $\mathrm{PO}_{4}^{3-}$ , were strongly correlated with the distribution of microbial species on which $\mathrm{NH}_{4}^{-}$, TP and $\mathrm{PO}_{4}^{3-}$ concentrations had significant effects. These results suggested that, high levels of nutrient status promoted diversity and distribution of microbial species within the community. It has also been shown that, shifts in the structure of bacterial communities can be associated with changes in a number of soil properties including soil texture and soil nitrogen availability [30,31]. On the other hand, Calheiros et al. [32] reported that, bacterial diversity in constructed wetland may be a significant driver influencing the final effluent quality. Ogier et al. [33] and Dubernet et al. [34] reported that, the difference in the relative abundance of community members may affect the detection 
of certain species due to competition during PCR. However, there may well be some species whose presence was obscured because they were not detected by pyrosequencing. Our study showed that, when wetland samples were analyzed spatially, community structures from wetland samples associated with the swine house and lagoons 1 and 2 were significantly different $(\mathrm{P}<0.0001)$ based on parsimony test of UniFrac data (Figure 3A) from storage tanks, wetland cells effluent, storage pond, and the final effluent. Microbial communities in wetland cells are highly responsive to perturbation, dissolved organic matter concentration, and chemical stress, among others [35-38].

Pyrosequencing data showed high levels of Bacillus which is one of the largest Eubacteria found in soil. Some bacilli are phosphate solubilizing and are capable of surviving in extreme conditions due to their ability to form spores. Han and Lee [39] reported that, the inoculation of certain species of Bacillus may increase soil $\mathrm{P}$ availability. The high concentration of $\mathrm{P}$ in swine wastewater will limit the assimilative capacity of wetland soil and the presence of such bacteria in our constructed wetlands for swine wastewater treatment could impair the capabilities of $\mathrm{P}$ nutrient removal. A high relative abundance of potential denitrifying bacteria, Flavobacterium, was detected in midsection of the wetland. Flavobacterium associated with this wetland had been shown to be closely related to nitrifying bacteria [2]. However, these authors noted that even though these bacteria demonstrated phylogenic similarity, it does not mean that they have denitrifying potential. Therefore, the existence of denitrifying bacteria may be a contributing factor to the decreasing trend of nitrogen concentration from the influent to the effluent end in our wetland.

Another important pathway for the removal of nitrogen from this wetland is through the Anammox process. During this process, ammonium and nitrite are converted to dinitrogen gas [40]. Our research findings suggested the existence of Anammox bacterial sequences, Candidatus Solibacter, and this bacterium is a strict anaerobic autotroph. It is also known for its extremely slow growth resulting in limited applications [41]. Partial-nitrification with Anammox in constructed wetlands with higher removal efficiency of total nitrogen than conventional methods has also been reported [42], thus confirming the role of these group of bacteria in water quality improvements in constructed wetlands. It is possible that Anammox bacteria played a role in nitrogen removal in our wetland. It has been reported that Anammox uses carbon dioxide as its carbon source to produce biomass $\left(\mathrm{CH}_{2} \mathrm{O}_{0.5} \mathrm{~N}_{0.15}\right)$ and nitrite as electron acceptor for ammonium oxidation, and electron donor for the reduction of carbon dioxide [40]. In our study, we identify six OTUs of Candidatus Solibacter, whose sequences were $100 \%$ similar to Candidatus Solibacter from different sections of our wetland. This wetland has a high concentration of ammonium and nitrite, and as mentioned above [40], the Anammox bacteria require both ammonium and nitrite, which can be found at or near the aerobic-anaerobic interface of sediments and water bodies to function efficiently. Our samples were collected in the continuous flow section of the wetland which provides the most ideal region for the enrichment of Anammox. In constructed wetlands, ammonium diffuses upwards and meets the oxygen that is diffusing downwards, and create aerobe-anaerobe zone for most of the microbial activities associated aerobic bacteria or crenarchaeal ammonium oxidizers. In our study, about $5.1 \%$ of archaea were Crenarchaeota (Table 4). We also detected by pyrosequencing Nitrosopumilus which is a major ammonia oxidizing archaea $[22,29,43]$. These authors have shown that both bacteria and archaea communities can play important roles in biogeochemical processes in constructed wetland system.

In conclusion, the different sections of the wetland had different nutrient status reflecting different bacterial communities and diversities, permitting different bacteria to play important roles in nutrient removal within the wetland. The removal rates of $\mathrm{N}$ and $\mathrm{NH}_{4}^{+}$ in this study were above $70 \%$ from the influent to the effluent and this signifies the important roles of different microbial groups, played in contaminant removal. Most important, is the improvement of water quality from the final effluent since this water could be spread on the pasture. Therefore, the removal of the main pollutants from the swine wastewater would have a beneficial effect on the ground and surface water and in most of the swine producing regions of the world. This project is an innovative model for waste management for the swine industry and other confined-animal facilities.

\begin{tabular}{|c|c|c|c|c|c|c|c|c|c|}
\hline Taxon & Total & s1 & S2 & s3 & S4 & S5 & s6 & S7 & s8 \\
\hline Archaea & 100 & 100 & 100 & 100 & 100 & 100 & 100 & 100 & 100 \\
\hline Crenarchaeota & 1.2 & 0.16 & 0 & 0.16 & 1.45 & 1.97 & 2.5 & 1.84 & 8.15 \\
\hline Euryarchaeota & 97.64 & 99.84 & 100 & 99.68 & 98.01 & 94.49 & 92.14 & 90.18 & 78.52 \\
\hline pMC2A384 & 0.08 & 0 & 0 & 0 & 0.09 & 0 & 0 & 0.61 & 0.74 \\
\hline unclassified archaea & 1.09 & 0 & 0 & 0.16 & 0.45 & 3.54 & 5.36 & 7.36 & 12.59 \\
\hline \multicolumn{10}{|c|}{ Full sequence percentages of archaea classes } \\
\hline Taxon & Total & A.MU & A.sw & A.LA & A.MI & A.MM & A.ME & A.SP & A.FE \\
\hline C2 & 1.01 & 0 & 0 & 0.16 & 1.33 & 1.97 & 1.79 & 1.84 & 4.44 \\
\hline Methanobacteria & 15.62 & 62.38 & 20.59 & 22.46 & 2.53 & 18.9 & 18.57 & 33.13 & 19.26 \\
\hline Methanomicrobia & 59.34 & 0 & 3.36 & 25.04 & 93.64 & 65.35 & 54.29 & 52.76 & 52.59 \\
\hline pMC2A209 & 0.02 & 0 & 0 & 0 & 0.03 & 0 & 0 & 0 & 0 \\
\hline Thaumarchaeota & 0.16 & 0.16 & 0 & 0 & 0.09 & 0 & 0.71 & 0 & 2.96 \\
\hline Thermoplasmata & 22.3 & 37.46 & 76.05 & 52.02 & 1.84 & 4.72 & 17.86 & 4.29 & 2.96 \\
\hline unclassified archaea & 1.09 & 0 & 0 & 0.16 & 0.45 & 3.54 & 5.36 & 7.36 & 12.59 \\
\hline unclassified Crenarchaeota & 0.02 & 0 & 0 & 0 & 0 & 0 & 0 & 0 & 0.74 \\
\hline unclassified euryarchaeota & 0.38 & 0 & 0 & 0.16 & 0 & 5.51 & 1.43 & 0 & 3.7 \\
\hline unclassified pMC2A384 & 0.08 & 0 & 0 & 0 & 0.09 & 0 & 0 & 0.61 & 0.74 \\
\hline
\end{tabular}

Table 4: Full sequence percentages of archaea at the phylum and class levels. 
Citation: Ibekwe AM, Ma J, Murinda S, Reddy GB (2017) Microbial Diversity in Continuous Flow Constructed a Wetland for the Treatment of Swine Waste. Hydrol Current Res 8: 277. doi: 10.4172/2157-7587.1000277

Page 6 of 8

\begin{tabular}{|c|c|c|c|c|c|c|c|c|c|}
\hline Taxon & Total & S1 & S2 & S3 & S4 & S5 & S6 & S7 & S8 \\
\hline Acidobacteria & 0.07 & 0.08 & 0 & 0.06 & 0.04 & 0.5 & 0 & 0.02 & 0 \\
\hline Actinobacteria & 1.31 & 2 & 0.39 & 3.21 & 1.05 & 0.74 & 0.08 & 2.43 & 0.12 \\
\hline Armatimonadetes & 0.01 & 0.01 & 0 & 0 & 0.09 & 0.03 & 0 & 0 & 0 \\
\hline Bacteroidetes & 18.15 & 10.02 & 14.08 & 10.38 & 11.14 & 18.23 & 28.73 & 17.01 & 39.15 \\
\hline Chlorobi & 0.02 & 0 & 0 & 0.03 & 0.09 & 0 & 0 & 0 & 0 \\
\hline Chloroflexi & 0.13 & 0.07 & 0.08 & 0.24 & 0.39 & 0.23 & 0 & 0.01 & 0 \\
\hline Deferribacteres & 0 & 0 & 0 & 0 & 0 & 0 & 0 & 0 & 0.01 \\
\hline Fibrobacteres & 0.05 & 0 & 0.03 & 0 & 0 & 0 & 0.3 & 0 & 0.09 \\
\hline Firmicutes & 11.86 & 0.22 & 8.44 & 0.6 & 1.97 & 0.42 & 47.56 & 0.29 & 34.89 \\
\hline Fusobacteria & 0.01 & 0 & 0.04 & 0 & 0 & 0 & 0 & 0 & 0.04 \\
\hline Gemmatimonadetes & 0.02 & 0.02 & 0.01 & 0.01 & 0 & 0.12 & 0 & 0.01 & 0 \\
\hline Lentisphaerae & 0.01 & 0 & 0.03 & 0.01 & 0.02 & 0 & 0 & 0 & 0.01 \\
\hline OD1 & 0 & 0 & 0 & 0.01 & 0 & 0 & 0 & 0.01 & 0 \\
\hline Planctomycetes & 0.01 & 0.02 & 0 & 0.01 & 0.02 & 0.06 & 0 & 0.02 & 0 \\
\hline Proteobacteria & 36.58 & 27.39 & 58.49 & 60.1 & 66.36 & 29.59 & 1.19 & 29.13 & 7.44 \\
\hline Spirochaetes & 0.54 & 0 & 0.79 & 0.05 & 0.12 & 0.09 & 2.17 & 0 & 0.94 \\
\hline SR1 & 0 & 0 & 0.01 & 0 & 0 & 0 & 0 & 0 & 0 \\
\hline Tenericutes & 0.12 & 0 & 0.43 & 0.15 & 0.06 & 0.03 & 0.02 & 0 & 0.18 \\
\hline TM7 & 0.06 & 0.11 & 0 & 0.06 & 0.04 & 0.06 & 0 & 0.19 & 0 \\
\hline unclassified bacteria & 30.33 & 57.98 & 17.13 & 24.24 & 18.38 & 47.59 & 19.94 & 49.95 & 17.13 \\
\hline Verrucomicrobia & 0.73 & 2.09 & 0.04 & 0.86 & 0.24 & 2.32 & 0.01 & 0.94 & 0 \\
\hline Total & 100 & 100 & 100 & 100 & 100 & 100 & 100 & 100 & 100 \\
\hline
\end{tabular}

Table 5: Full sequence percentages of bacteria at the phylum level.

\begin{tabular}{|c|c|c|c|c|c|c|c|c|c|}
\hline Taxon & Total & s1 & S2 & S3 & S4 & S5 & S6 & S7 & S8 \\
\hline Basidiomycota & 87.26 & 97.26 & 92.58 & 76.48 & 81.03 & 85.98 & 89.09 & 95.56 & 45.36 \\
\hline unclassified fungi & 12.74 & 2.74 & 7.42 & 23.52 & 18.97 & 14.02 & 10.91 & 4.44 & 54.64 \\
\hline \multicolumn{10}{|c|}{ Full taxonomy RDP by order } \\
\hline & Total & F.FE & F.LA & F.ME & F.MI & F.MM & F.MU & F.SP & F.SW \\
\hline Agaricomycetes & 85.84 & 96.87 & 91.89 & 70.92 & 80.18 & 83.9 & 88.13 & 95.3 & 44.09 \\
\hline unclassified basidiomycota & 1.43 & 0.4 & 0.69 & 5.57 & 0.85 & 2.08 & 0.95 & 0.26 & 1.28 \\
\hline unclassified fungi & 12.74 & 2.74 & 7.42 & 23.52 & 18.97 & 14.02 & 10.91 & 4.44 & 54.64 \\
\hline \multicolumn{10}{|c|}{ Full taxonomy RDP by family } \\
\hline & Total & F.FE & F.LA & F.ME & F.MI & F.MM & F.MU & F.SP & F.SW \\
\hline Agaricales & 83.74 & 96.66 & 90.89 & 60.46 & 78.48 & 81.58 & 87.95 & 94.99 & 42.7 \\
\hline unclassified Agaricomycetes & 2.1 & 0.2 & 1 & 10.46 & 1.7 & 2.32 & 0.18 & 0.3 & 1.39 \\
\hline unclassified basidiomycota & 1.43 & 0.4 & 0.69 & 5.57 & 0.85 & 2.08 & 0.95 & 0.26 & 1.28 \\
\hline unclassified fungi & 12.74 & 2.74 & 7.42 & 23.52 & 18.97 & 14.02 & 10.91 & 4.44 & 54.64 \\
\hline \multicolumn{10}{|c|}{ Full taxonomy RDP by genus } \\
\hline & Total & F.FE & F.LA & F.ME & F.MI & F.MM & F.MU & F.SP & F.SW \\
\hline Pleurotaceae & 81.84 & 95.66 & 90.67 & 51.94 & 75.41 & 80.17 & 87.94 & 93.67 & 42.55 \\
\hline unclassified Agaricales & 1.9 & 1.01 & 0.22 & 8.52 & 3.07 & 1.41 & 0.02 & 1.33 & 0.14 \\
\hline unclassified Agaricomycetes & 2.1 & 0.2 & 1 & 10.46 & 1.7 & 2.32 & 0.18 & 0.3 & 1.39 \\
\hline unclassified basidiomycota & 1.43 & 0.4 & 0.69 & 5.57 & 0.85 & 2.08 & 0.95 & 0.26 & 1.28 \\
\hline unclassified fungi & 12.74 & 2.74 & 7.42 & 23.52 & 18.97 & 14.02 & 10.91 & 4.44 & 54.64 \\
\hline \multicolumn{10}{|c|}{ Full taxonomy RDP by species } \\
\hline & Total & F.FE & F.LA & F.ME & F.MI & F.MM & F.MU & F.SP & F.SW \\
\hline Hohenbuehelia & 81.84 & 95.66 & 90.67 & 51.94 & 75.41 & 80.17 & 87.94 & 93.67 & 42.55 \\
\hline unclassified Agaricales & 1.9 & 1.01 & 0.22 & 8.52 & 3.07 & 1.41 & 0.02 & 1.33 & 0.14 \\
\hline unclassified Agaricomycetes & 2.1 & 0.2 & 1 & 10.46 & 1.7 & 2.32 & 0.18 & 0.3 & 1.39 \\
\hline unclassified basidiomycota & 1.43 & 0.4 & 0.69 & 5.57 & 0.85 & 2.08 & 0.95 & 0.26 & 1.28 \\
\hline unclassified fungi & 12.74 & 2.74 & 7.42 & 23.52 & 18.97 & 14.02 & 10.91 & 4.44 & 54.64 \\
\hline
\end{tabular}

Table 6: Full sequence percentages of some dominant Fungi from phylum to species. 
Citation: Ibekwe AM, Ma J, Murinda S, Reddy GB (2017) Microbial Diversity in Continuous Flow Constructed a Wetland for the Treatment of Swine Waste. Hydrol Current Res 8: 277. doi: 10.4172/2157-7587.1000277

\begin{tabular}{|c|c|c|}
\hline AOB & Nitrosomonas & 11 \\
\hline CD & Roseburia & 124 \\
\hline DN & Flavobacterium & 1626 \\
\hline DN & Rhodobacter & 28 \\
\hline DN & Thauera & 57 \\
\hline DN & Methylophilus & 3 \\
\hline HOB & Hydrogenophaga & 7116 \\
\hline anammox & CandidatusSolibacter & 6 \\
\hline AOA & Nitrosopumilus & 4 \\
\hline
\end{tabular}

AOB- ammonia oxidizing bacteria, CD- carbon degrader, DN- denitrifying bacteria, HOB-hydrogen oxidizing bacteria, anammox- anaerobic ammonia oxidizing bacterium, AOA- ammonia oxidizing archaea.

Table 7: Bacteria and archaea with potential contribution for removal of contaminants from constructed wetlands.

\section{Acknowledgements}

This research was supported by the 212 Manure and Byproduct Utilization Project of the USDA-ARS. We thank Damon Baptista for technical assistance. Mention of trade names or commercial products in this publication is solely for the purpose of providing specific information and does not imply recommendation or endorsement by the U.S. Department of Agriculture. The US Department of Agriculture (USDA) prohibits discrimination in all its programs and activities on the basis of race, color, national origin, age, disability, and where applicable, sex, marital status, familial status, parental status, religion, sexual orientation, genetic information, political beliefs, reprisal, or because all or part of an individual's income is derived from any public assistance program.

\section{References}

1. Ibekwe AM, Grieve CM, Lyon SR (2003) Characterization of microbial communities and composition in constructed dairy wetland wastewater effluent. Appl Environ Microbiol 69: 5060-5069.

2. Dong X, Reddy GB (2010) Soil bacterial communities in constructed wetlands treated with swine wastewater using PCR-DGGE technique. Bioresour Technol 101: 1175-1182.

3. Oopkaup K, Truu M, Nõlvak H, Ligi T, Preem JK (2016) Dynamics of bacterial community abundance and structure in horizontal subsurface flow wetland mesocosms treating municipal wastewater.Water 8: 457

4. Ibekwe AM, Ma J, Murinda SE, Reddy GB (2016) Bacterial community dynamics in surface flow constructed wetlands for the treatment of swine waste. Sc Total Environ 544: 68-76.

5. Ibekwe AM, Murinda SE, DebRoy C, Reddy GB (2016) Potential pathogens, antimicrobial patterns, and genotypic diversity of Escherichia coli isolates in constructed wetlands treating swine wastewater. FEMS Microbiol Ecol 92 $1-14$.

6. Ibekwe AM, Lyon SR, Leddy M, Jacobson-Meyer M (2007) Impact of plan density and microbial composition on water quality from a free water surface constructed wetlands. J Appl Microbiol 102: 921-936.

7. Kadlec RH, Knight RL (1996) Treatment wetlands. Lewis Publishers, New York 1996.

8. Casteel MJ, Sobsey MD, Mueller JP (2006) Fecal contamination of agricultural soils before and after hurricane-associated flooding in North Carolina. J Environ Sci Health Part A 41: 173-184.

9. Reddy GB, Hunt PG, Phillips R, Stone K, Grubbs A (2001) Treatment of swine wastewater in marsh-pond-marsh constructed wetlands. Water Sci Technol 44 545.

10. Scholz M, Lee BH (2005) Constructed wetlands: a review. Int J Environ Stud 62: $1256-1261$

11. Forbes DA, Reddy GB, Hunt PG, Poach ME, Ro KS et al. (2010) Comparison of aerated marsh-pond-marsh and continuous marsh constructed wetlands for treating swine wastewater. J Environ Sc Health 45: 803-809.

12. Dowd SE, Callaway TR, Wolcott RD, Sun Y, McKeehan T et al. (2008) Evaluation of the bacterial diversity in the feces of cattle using 16S rDNA bacterial tagencoded FLX amplicon pyrosequencing (bTEFAP). BMC Microbiol 8: 125.

13. Schloss PD, Westcott SL, Ryabin T, Hall JR, Hartmann M, et al. (2009) Introducing mothur: open-source, platform-independent, community-supported software for describing and comparing microbial communities. Appl Environ Microbiol 75: 7537-7541.

14. Cole JR, Wang Q, Cardenas E, Fish J, Chai B, et al. (2009) The Ribosomal Database Project: improved alignments and new tools for rRNA analysis. Nucleic Acids Res 37: D141-D145.

15. Claesson M, O'Sullivan O, Wang Q, Nikkila J, Marchesi J, et al. (2009) Comparative analysis of pyrosequencing and a phylogenetic microarray for exploring microbial community structures in the human distal intestine. PloS One 4: e6669.

16. Champely S, Chessel D (2002) Measuring biological diversity using Euclidean metrics. Environ Ecol Stat 9: 167-177.

17. SAS Institute (2009). JMP User guide. Release 9.1. SAS Inst Cary, NC.

18. Hamady M, Lozupone C, Knight R (2010) Fast UniFrac: facilitating highthroughput phylogenetic analyses of microbial communities including analysis of pyrosequencing and PhyloChip data. ISMEJ 4: 17-27.

19. Sheneman L, Evans J, Foster JA (2006) Clearcut: a fast implementation of relaxed neighbor joining. Bioinformatics 22: 2823-2824.

20. Schloss PD, Handelsman J (2006) Introducing treeclimber, a test to compare microbial community structures. Appl Environ Microbiol 72: 2379-2384.

21. Poach ME, Hunt PG, Reddy GB, Stone KC, Johnson MH, et al. (2004) Swine wastewater treatment by marsh-pond-marsh constructed wetlands under varying nitrogen loads. Ecol Eng 23: 165-175.

22. Hatzenpichler R (2012) Diversity, physiology, and niche differentiation of ammonia-oxidizing archaea. Appl Environ Microbiol 78: 7501-7510.

23. Ibekwe AM, Leddy M, Murinda SE (2013) Potential human pathogenic bacteria in a mixed urban watershed as revealed by pyrosequencing. PLoS ONE 11 e79490.

24. Gersberg RM, Elkins BV, Lyon SR, Goldman CR (1986) Role of aquatic plants in wastewater treatment by artificial wetlands. Water Res 20: 363-368.

25. Ipsilantis I, Sylvia DM (2007) Abundance of fungi and bacteria in a nutrientimpacted Florida wetland. Appl Soil Ecol 35: 272-280.

26. Oehl F, Frossard E, Fliessbach A, Dubois D, Oberson A (2004) Basal organic phosphorus mineralization in soils under different farming systems. Soil Biol Biochem 36: 667-675.

27. Sundberg C, Tonderski K, Lindgren PE (2007) Potential nitrification and denitrification and the corresponding composition of the bacterial communities in a compact constructed wetland treating landfill leachates. Water Sci Technol 56: 159-166.

28. Truu J, Nurk K, Juhanson J, Mander U (2005) Variation of microbiological parameters within planted soil filter for domestic wastewater treatment. J Environ Sci Health Part A: Toxic/Hazard Subst Environ Eng 40: 1191-200.

29. Long Y, Yi H, Chen S, Zhang Z, Cui K, et al. (2016) Influences of plant type on bacterial and archaeal communities in constructed wetland treating polluted river water. Environ Sci Pollut Res 23: 19570-19579.

30. Frey SD, Knorr M, Parrent JL, Simpson RT (2004) Chronic nitrogen enrichment affects thee structure and function of the soil microbial community in temperate hardwood and pine forests. Forest Ecol Manage 196: 159-171.

31. Lauber CL, Strickland MS, Bradford MA, Fierer N (2008) The influence of soil properties on the structure of bacterial and fungal communities across land-use types. Soil Biol Biochem 40: 2407-2415

32. Calheiros CSC, Duque AF, Moura A, Henriques IS, Correia A, et al. (2009) Substrate effect on bacterial communities from constructed wetlands planted with Typha latifoliatreating industrial wastewater. Ecol Eng 35: 744-753.

33. Ogier JC, Son O, Gruss A, Tailliez P, Delacroix-Buchet A (2002) Identification of the bacterial microflora in dairy products by temporal temperature gradient gel electrophoresis. Appl Environ Microbiol 68: 3691-3701.

34. Dubernet SH, Desmasuress N, Guéguen M (2004) Culture-dependent and culture-independent methods for molecular analysis of the diversity of lactobacilli in "Camembert de Normandie" cheese. Lait 84: 179-189. 
Citation: Ibekwe AM, Ma J, Murinda S, Reddy GB (2017) Microbial Diversity in Continuous Flow Constructed a Wetland for the Treatment of Swine Waste. Hydrol Current Res 8: 277. doi: 10.4172/2157-7587.1000277

Page 8 of 8

35. Bodtker G, Thorstenson T, Lillebo BLP, Thorbjornsen BE, Ulvoen RH et al. (2008) The effect of long-term nitrate treatment on SRB activity, corrosion rate and bacterial community composition in offshore water injection systems. J Ind Microbiol Biotechnol 35: 1625-1636.

36. Wassel RA, Mills AL (1983) Changes in water and sediment bacterial community structure in a lake receiving acid-mine drainage. Microbial Ecology 9: 155-169.

37. Nelson CE (2009) Phenology of high-elevation pelagic bacteria: the roles of meteorologic variability, catchment inputs and thermal stratification in structuring communities. ISME J 3: 13-30.

38. Hirayama H, Takai K, Inagaki F, Yamato Y, Suzuki M, et al. (2005) Bacterial community shift along a subsurface geothermal water stream in a Japanese gold mine. Extremophiles 9: 169-184.
39. Han HS, Lee KD (2005) Phosphate and potassium solubilizing bacteria effect on mineral uptake, soil availability and growth of Eggplant. Res J Agric Biol Sci 1: $176-180$.

40. Kuenen JG (2008) Anammox bacteria: From discovery to application. Nat Rev Microbiol 4: 320-326.

41. Pathak BK, Kazama FF, Tanaka Y, Mori K, Sumino T (2007) Quantification of anammox populations enriched in an immobilized microbial consortium with low levels of ammonium nitrogen and at low temperature. Appl Microbio Biotechnol 76: 1173-1179.

42. Dong Z, Sun $T$ (2007) A potential new process for improving nitrogen removal in constructed wetlands-promoting coexistence of partial-nitrification and ANAMMOX. Ecol Eng 31: 69-78.

43. Stahl DA, de la Torre JR (2012) Physiology and diversity of ammonia-oxidizing archaea. Annu Rev Microbiol 66: 83-110. 